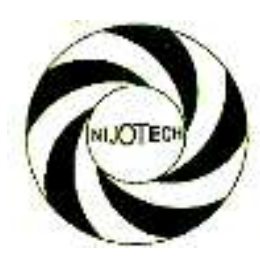

Nigerian Journal of Technology (NIJOTECH)

Vol. 38, No. 1, January 2019, pp. 242 - 252

Copyright@ Faculty of Engineering, University of Nigeria, Nsukka,

Print ISSN: 0331-8443, Electronic ISSN: 2467-8821 www.nijotech.com

http://dx.doi.org/10.4314/njt.v38i1.29

\title{
AIR QUALITY ASSESSMENT OF SOME OIL FACILITIES HOST COMMUNITIES IN RIVERS STATE
}

\author{
R. C. Osaiyuwu ${ }^{1}$ and J. N. Ugbebor ${ }^{2, *}$ \\ 1, INST. OF NAT. RES., ENVIRONMENT \& SUSTAINABILITY (INRES), Univ. OF PORT HARCOURT, RIVERS STATE, NIGERIA \\ 2, Department of Civil and Environmental Engineering, University of Port HaRCourt, Rivers State, NIGERIA \\ E-mail addresses: ${ }^{1}$ ritanath@ymail.com, ${ }^{2}$ johnugbebor@yahoo.com
}

\begin{abstract}
The study evaluated air quality around host communities of oil companies in Ogba/Egbema/Ndoni Local Government Area in Rivers state. Detailed literature reviews and appropriate multi-gas observing instruments were utilized to obtain air quality information. Results of $\mathrm{SO}_{2}$ in Omoku, Obrikum, Ebocha land Control (5km) from Oil Company indicated $214.1 \mu \mathrm{g} / \mathrm{m}^{3}, 0 \mu \mathrm{g} / \mathrm{m}^{3}$, $71.4 \mu \mathrm{g} / \mathrm{m}^{3}$ and $28.5 \mu \mathrm{g} / \mathrm{m}^{3}$. $\mathrm{NO}_{2}$ was $106 \mu \mathrm{g} / \mathrm{m}^{3}, 0.0 \mu \mathrm{g} / \mathrm{m}^{3}, 51,3 \mu \mathrm{g} / \mathrm{m}^{3}$ and $0.0 \mu \mathrm{g} / \mathrm{m}^{3}$ respectively. $\mathrm{CH}_{4}$ was $98,120 \mu \mathrm{g} / \mathrm{m}^{3}, 35,680 \mu \mathrm{g} / \mathrm{m}^{3}$ and $44600 \mu \mathrm{g} / \mathrm{m}^{3}$ and $28.7 \mu \mathrm{g} / \mathrm{m}^{3}$ respectively. PM 2.5 was $54 \mu \mathrm{g} / \mathrm{m}^{3}, 50.5 \mu \mathrm{g} / \mathrm{m}^{3}, 64 \mu \mathrm{g} / \mathrm{m}^{3}$ and $50 \mu \mathrm{g} / \mathrm{m}^{3}$ respectively. CO was $93.8 \mu \mathrm{g} / \mathrm{m}^{3}, 62.8 \mu \mathrm{g} / \mathrm{m}^{3}$, $78.1 \mu \mathrm{g} / \mathrm{m}^{3}$ and $0.0 \mu \mathrm{g} / \mathrm{m}^{3}$ respectively while $P M_{10}$ was $36 \mu \mathrm{g} / \mathrm{m}^{3}, 32 \mu \mathrm{g} / \mathrm{m}^{3}, 35.5 \mu \mathrm{g} / \mathrm{m}^{3}$ and $24 \mu \mathrm{g} / \mathrm{m}^{3}$ respectively. Results indicated that host communities were exposed to reasonable concentrations of air pollutants, especially hydrocarbon, carbon monoxide, nitrogen dioxide, and PM 2.5 Which fall within moderate to severe air pollution level. The statistical analysis of results using ANOVA showed that the difference among the pollutants characteristics at $p<0.05$ are statistically significant. Federal and state governments should pay particular attention to air pollution problems in the study area by establishing air quality monitoring stations through relevant agencies.
\end{abstract}

Keywords: Pollution, Concentration, Sensitive people, Air quality index, air pollution index, host communities

\section{INTRODUCTION}

One of the key issues and challenges that the world is facing today is environmental pollution. Nigeria is known to be one of the leading natural gas flaring countries in the world [1]; flaring proportionally, about 46 percent of Africa's total flaring. Cedigaz [2] and associated gas worth $\$ 1.04$ billion per year. These flares emanate from oil and gas facilities, most of which are located in the Niger Delta. The danger of continuous flaring of associated oil and gas is that it may become a source of air pollution which changes the composition of atmosphere and affect the biotic environment and threatened the health of humans, vegetation, as well as damage the ozone layer and buildings [3-5]. Concentration of air pollutant depends on the quantities of gas emitted by source facilities and the ability of the atmosphere to absorb or disperse these emissions. Many studies have been carried out on air quality over the years yet air pollution issue remains a serious threat to environmental health in many cities of the world [68] and particularly the oil producing area of Niger Delta of Nigeria [9].

Various pollutants enter the atmosphere through natural and anthropogenic processes such as domestic sources, flaring, vehicular and industrial emissions. High concentration of pollutants such as NOx, CO, SOx, VOC, Total Hydrocarbon Content (THC), $\mathrm{H}_{2} \mathrm{~S}$, and Total Suspended particles (TSP)when released to the atmosphere from oil facilities and other anthropogenic sources may constitute environmental and health risks [1, 10-13]. It is known to also contribute to climate change, global warming, environmental pollution, increased carbon foot print and acid rain. Genuine efforts have been made by oil and gas companies in harnessing 
associated gas to reduce the amount flared gas into the environment in Nigeria [14], yet flaring is largely seen in most oil and gas facilities in the Niger Delta. Oil exploration and production came with a lot of complex activities, laden with environmental issues and challenges including air and noise pollution since its inception in later years of 1950's [15]. The study area is a crucial factor in the development of Rivers State and the entire nation at large and due to the high concentration of oil facilities owed by the multinational companies. [16, 17, 15].The host communities have become the focal interest for air quality study to confirm their environmental health condition.

\section{METHODOLOGY}

\subsection{Study Area}

The study area (Figure 1) is located between latitude $5.383^{\circ}$ North and $5.433^{\circ}$ North; and longitude $6.55^{\circ}$ East and $6.70^{\circ}$ East [9]. The area hosts major oil companies' such as the Nigeria Agip Oil Company
(NAOC), Total Exploration and Production Nigeria Limited (TEPEG) and SHELL Petroleum Development Company (SPDC).Air quality monitoring was carried out within the host communities of Omoku town, Obrikom town and Ebocha town as shown in Figure 1 in accordance to statutory requirements.

\subsection{Research Design}

The field survey was conducted to assess the existing air quality condition of the study area, and to determine the likely impacts of the oil and Gas facilities operation on potential sensitive receptors in the area. Relevant literatures were reviewed and standard instruments were deployed to carry out the study. Sensitive human settlements in the study area were identified and monitored during field exercise. Map of study area indicating major communities of interest were shown, and measured field data were analysed and presented in Tables and Graphical forms.

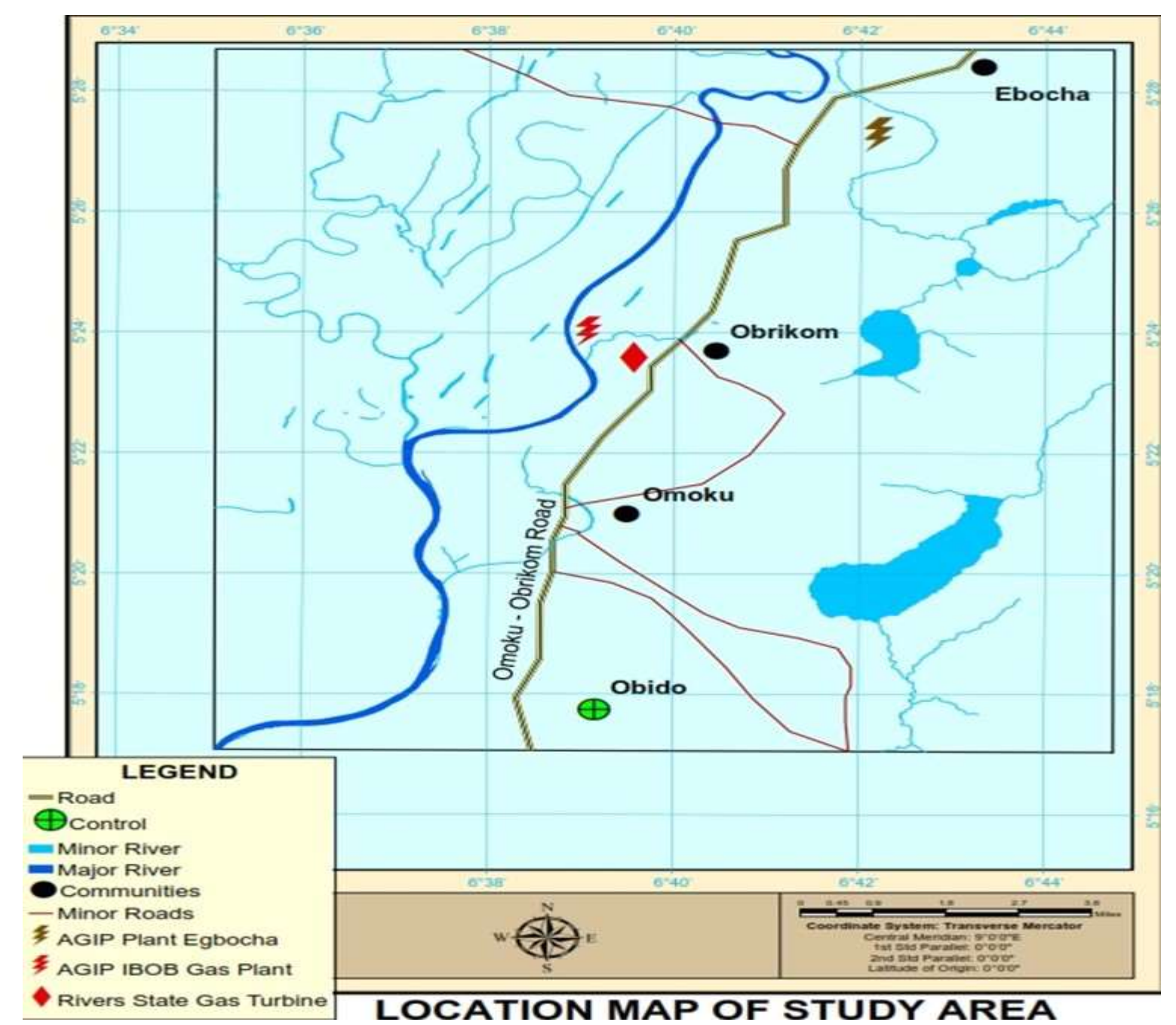

Map 1: Schematic Map of Study Area (source: [9]) 
Table 1: Monitoring locations and coordinates

\begin{tabular}{lll}
\hline $\mathrm{S} / \mathrm{N}$ & Location & Coordinates \\
\hline 4 & Omoku Town & $\mathrm{E} 6^{0} 39^{\prime} 28.914^{\prime \prime} \mathrm{N} 5^{0} 20^{\prime} 59.189^{\prime \prime}$ \\
5 & Obrikom Town & $\mathrm{E} 6^{0} 66^{\prime} 85.300^{\prime \prime} \mathrm{N} 5^{0} 39^{\prime} 48.200^{\prime \prime}$ \\
6 & Ebocha Town & $\mathrm{E} 6^{0} 41^{\prime} 54.900^{\prime \prime} \mathrm{N} 5^{0} 27^{\prime} 34.500^{\prime \prime}$ \\
7 & Control(5Km) & $\mathrm{E} 7^{0} 10^{\prime} 11.106^{\prime \prime} \mathrm{N} 4^{0} 42^{\prime} 9.991^{\prime \prime}$ \\
\hline
\end{tabular}

\subsection{Monitoring Locations}

Four areas (three host communities within the study area and one control) were monitored for air pollutants. The control location was chosen about 5 $\mathrm{km}$ from study area and monitored. The monitoring points and their coordinates are shown in Table 1.

\subsection{Materials and Equipment}

Air samplings were achieved using the Enerac 700, a multi-gas analyser. The multi-gas analyser gave an instantaneous reading and results recorded in real time [18]. The equipment was programmed at a range of 3 metres above ground level using a standard tripod cord at the respective sampling locations. Regular intervals of sampling were done for a period of 4 hours in compliance to standard guidelines of [19] during the dry season. Air Metrics Minivol Particulate Sampler and Garmin/Met One Instrument Aerosol Mass Monitor was employed for suspended particulate matter (SPM, $\mathrm{PM}_{10}, \mathrm{PM}_{2.5}$, etc.), and visible infrared spectrometer was used to analyze the absorbent solution. Digital Compass and Geographic Positioning System (GPS) was deployed to record distances and coordinates. Multi-purpose digital Kestrel 4500 digital Anemometer (that measures air Hydro thermo-anemometer, velocity, temperature and humidity) was used to measure wind speed, temperature and relative humidity, while wind vane was used to determine the wind direction. The Air Pollution Index (API) of each community was determined using the formula according to [20]:

$$
\begin{aligned}
A P I & =\frac{1}{n} \sum_{i=1}^{n} A_{i} \\
A_{i} & =\frac{C_{i}}{S_{i}} \times 100
\end{aligned}
$$

Where API is the Air pollution Index, $C_{i}$ is the concentration of pollutants, $\mathrm{Si}$ is the Air quality standard for pollutant, and $A_{i}$ is the Rating scale for Air Pollution Indices (API). A typical Rating Scale for API is given in [20].

\section{RESULTS}

Results of the monitoring exercise for each location within the study area and its environs were presented in Tables 3-5. The total average values of each pollutant for the communities were shown in Table 6 and Figures 1-8. Ranking of air pollutants for monitored area were presented in Table 8. Distances of sensitive receptors to oil companies were shown in Table 8. Values of the wind rose of the area was shown in Figures 9.

\section{DISCUSSION}

The Results in Table 3-6 and Figure 4indicated that $\mathrm{CH}_{4}$ at Omoku, Obrikom and Ebocha Towns were $98,120 \mathrm{ug} / \mathrm{m}, \quad{ }^{3} 35680 \mathrm{ug} / \mathrm{m}^{3}$ and $44,600 \mathrm{ug} / \mathrm{m}^{3}$ respectively. These exceeded Federal Ministry of Environment (FMEnv) limit of $160 \mu \mathrm{g} / \mathrm{m}^{3}$. The $\mathrm{CH}_{4}$ at Omoku, Obrikom and Ebocha Towns were rated as high and therefore unhealthy public health wise.This is in line with the study of carried out by [1] which revealed that the oil and gas facilities were the main sources of air pollution in the area. Past study in the same area by [22, 9] indicated a very high methane concentration and established that flora, fauna and properties may continually be impacted if nothing is done to eliminate gas flaring. According to [23] methane gas has been associated with oil and gas production and constitutes $70 \%$ and $90 \%$ of natural gas. Also, high threshold of methane hydrocarbon may result in chronic health effects among host community [24 - 26].

Table 2: API Rating Scale Source: [20, 21]

\begin{tabular}{lll}
\hline Index value & Rating & Classification \\
\hline $0-25$ & Clear air & Good \\
$26-50$ & Light air pollution & Acceptable \\
$51-75$ & Moderate air pollution & Unsatisfactory \\
$76-100$ & Heavy air pollution & Unhealthy \\
$>100$ & Severe air pollution & Severe and unhealthy \\
\hline
\end{tabular}


Table 3 Ambient Air quality monitoring data in Omoku Town

\begin{tabular}{|c|c|c|c|c|c|c|c|c|c|c|c|c|c|}
\hline $\begin{array}{c}\text { Communi } \\
\text { ty }\end{array}$ & $\begin{array}{c}\text { Hourly } \\
\text { Readings }\end{array}$ & $\begin{array}{l}\text { Temp } \\
\left({ }^{\circ} \mathrm{C}\right)\end{array}$ & $\begin{array}{c}\text { Rel. } \\
\text { Humid } \\
(\%)\end{array}$ & $\begin{array}{l}\text { Wind } \\
\mathrm{spd} \\
(\mathrm{m} / \mathrm{s})\end{array}$ & $\begin{array}{c}\text { Win } \\
d \\
\text { dire } \\
c t\end{array}$ & $\begin{array}{c}\mathrm{SO}_{2} \\
\left(\mu \mathrm{g} / \mathrm{m}^{3}\right. \\
)\end{array}$ & $\begin{array}{c}\mathrm{NO}_{2} \\
\left(\mu \mathrm{g} / \mathrm{m}^{3}\right. \\
)\end{array}$ & $\begin{array}{c}\mathrm{CO} \\
\left(\mu \mathrm{g} / \mathrm{m}^{3}\right. \\
)\end{array}$ & $\begin{array}{c}\mathrm{H}_{2} \mathrm{~S} \\
\left(\mu \mathrm{g} / \mathrm{m}^{3}\right. \\
)\end{array}$ & $\begin{array}{c}\mathrm{CH}_{4} \\
\left(\mu \mathrm{g} / \mathrm{m}^{3}\right)\end{array}$ & $\begin{array}{c}\mathrm{TSP} \\
\left(\mu \mathrm{g} / \mathrm{m}^{3}\right. \\
)\end{array}$ & $\begin{array}{c}\mathrm{PM}_{10} \\
(\mu \mathrm{g} / \\
\left.\mathrm{m}^{3}\right)\end{array}$ & $\begin{array}{c}\mathrm{PM}_{2.5} \\
\left(\mu \mathrm{g} / \mathrm{m}^{3}\right. \\
)\end{array}$ \\
\hline \multirow{7}{*}{$\begin{array}{l}\text { Omoku } \\
\text { Town }\end{array}$} & 1 & 30.9 & 77.4 & 1.2 & $\mathrm{NE}$ & 285.4 & $\mathrm{ND}$ & ND & 151.6 & 214080.0 & 51.0 & 26.0 & 52.0 \\
\hline & 2 & 31.3 & 75.2 & 1.1 & NW & ND & 205.2 & 125.0 & ND & 71360.0 & 72.0 & 37.0 & 61.0 \\
\hline & 3 & 31.8 & 73.7 & 1.0 & $\mathrm{NE}$ & 285.4 & 205.2 & 0.0 & ND & 71360.0 & 66.0 & 42.0 & 58.0 \\
\hline & 4 & 32.1 & 69.8 & 1.4 & $\mathrm{NE}$ & 285.4 & ND & 250.0 & ND & 35680.0 & 70.0 & 39.0 & 45.0 \\
\hline & & 30.9 & $69.8-$ & 1.0 & & $0.0-$ & 0.0 & $0.0-$ & 0.0 & $35680-$ & 51.0 & 26.0 & $45.0-$ \\
\hline & Range & 32.1 & 75.2 & 1.4 & & 285.4 & 205.2 & 250.0 & 151.6 & 214080 & 72.0 & 42.0 & 61.0 \\
\hline & Mean & 31.5 & 74.0 & 1.2 & & 214.1 & 102.6 & 93.8 & 37.9 & 98120.0 & 64.8 & 36.0 & 54.0 \\
\hline $\begin{array}{l}\text { FMEnvlim } \\
\text { it }\end{array}$ & & & & & & 260 & 75 & 22.8 & NA & 160 & 250 & NA & NA \\
\hline $\begin{array}{l}\text { NAAQS } \\
\text { limit }\end{array}$ & & & & & & 365 & 188.7 & 10000 & NA & NA & 200 & 150 & 35 \\
\hline
\end{tabular}

$\mathrm{ND}=$ Not detected $; \mathrm{NA}=$ Not available

Table 4: Result of Ambient Air quality monitoring in Obrikom Town

\begin{tabular}{|c|c|c|c|c|c|c|c|c|c|c|c|c|c|}
\hline Community & $\begin{array}{l}\text { Hourly } \\
\text { Readings }\end{array}$ & $\begin{array}{l}\text { Temp } \\
\left({ }^{\circ} \mathrm{C}\right)\end{array}$ & $\begin{array}{l}\text { Rel. } \\
\text { Humi } \\
\text { d. } \\
(\%)\end{array}$ & $\begin{array}{l}\text { Wind } \\
\mathrm{spd} \\
(\mathrm{m} / \mathrm{s})\end{array}$ & $\begin{array}{l}\text { Wn } \\
d \\
\text { dire } \\
\text { ct }\end{array}$ & $\begin{array}{l}\mathrm{SO}_{2} \\
(\mu \mathrm{g} / \mathrm{m} \\
\left.{ }_{3}\right)\end{array}$ & $\begin{array}{l}\mathrm{NO}_{2} \\
(\mu \mathrm{g} / \mathrm{m} \\
3)\end{array}$ & $\begin{array}{l}C O \\
\left(\mu \mathrm{g} / \mathrm{m}^{3}\right. \\
)^{2}\end{array}$ & $\begin{array}{l}\mathrm{H}_{2} \mathrm{~S} \\
(\mu \mathrm{g} / \mathrm{m} \\
\left.{ }_{3}\right)\end{array}$ & $\begin{array}{l}\mathrm{CH}_{4} \\
\left(\mu \mathrm{g} / \mathrm{m}^{3}\right)\end{array}$ & $\begin{array}{l}\text { TSP } \\
(\mu \mathrm{g} / \mathrm{m} \\
3)\end{array}$ & $\begin{array}{l}\text { PM10 } \\
(\mu \mathrm{g} / \mathrm{m} \\
\left.{ }^{2}\right)\end{array}$ & $\begin{array}{l}\text { PM2.5 } \\
\left(\mu \mathrm{g} / \mathrm{m}^{3}\right. \\
)^{3}\end{array}$ \\
\hline & 1 & 31.1 & 78.2 & 0.8 & $\mathrm{NE}$ & ND & ND & 126.0 & ND & ND & 49.0 & 21.0 & 48.0 \\
\hline Obrikom & 2 & 31.4 & 77.6 & 0.9 & NW & ND & ND & ND & ND & 71360.0 & 53.0 & 28.0 & 55.0 \\
\hline \multirow[t]{4}{*}{ Town } & 3 & 32.0 & 72.1 & 1.3 & NW & ND & ND & 125.0 & ND & 35680.0 & 50.0 & 37.0 & 42.0 \\
\hline & 4 & 32.2 & 64.8 & 1.1 & $\mathrm{NE}$ & ND & ND & ND & ND & 35680.0 & 61.0 & 42.0 & 57.0 \\
\hline & Range & $\begin{array}{l}31.1- \\
32.2\end{array}$ & $\begin{array}{l}64.8- \\
78.2\end{array}$ & $0.8-1.3$ & & & & $\begin{array}{l}0.0- \\
125.0\end{array}$ & & $\begin{array}{l}0.0- \\
71360\end{array}$ & $\begin{array}{l}49.0- \\
61.0\end{array}$ & $\begin{array}{l}21.0- \\
42.0\end{array}$ & $\begin{array}{l}42.0- \\
57.0\end{array}$ \\
\hline & Mean & 31.7 & 73.2 & 1.7 & & & & 62.8 & & 35680.0 & 53.3 & 32.0 & 50.5 \\
\hline FMEnvlimit & & & & & & 260 & 75 & 22.8 & NA & 160 & 250 & NA & NA \\
\hline NAAQS limit & & & & & & 365 & 188.7 & 10000 & NA & NA & 200 & 150 & 35 \\
\hline
\end{tabular}

ND- Not detect;NA- Not available

Table 5: Results of Ambient Air quality monitoring in Ebocha Town

\begin{tabular}{|c|c|c|c|c|c|c|c|c|c|c|c|c|c|}
\hline $\begin{array}{l}\text { Communit } \\
\text { y }\end{array}$ & $\begin{array}{l}\text { Hourly } \\
\text { Readings }\end{array}$ & $\begin{array}{l}\text { Temp } \\
\left({ }^{\circ} \mathrm{C}\right)\end{array}$ & $\begin{array}{l}\text { Rel. } \\
\text { Humid. } \\
(\%)\end{array}$ & $\begin{array}{l}\text { Wind } \\
\text { spd } \\
(\mathrm{m} / \mathrm{s})\end{array}$ & $\begin{array}{l}\text { Wn } \\
d \\
\text { dire } \\
c t\end{array}$ & $\begin{array}{l}\mathrm{SO}_{2} \\
\left(\mu \mathrm{g} / \mathrm{m}^{3}\right. \\
)^{2}\end{array}$ & $\begin{array}{l}\mathrm{NO}_{2} \\
\left(\mu \mathrm{g} / \mathrm{m}^{3}\right. \\
)\end{array}$ & $\begin{array}{l}\mathrm{CO} \\
\left(\mu \mathrm{g} / \mathrm{m}^{3}\right. \\
)^{3}\end{array}$ & $\begin{array}{l}\mathrm{H}_{2} \mathrm{~S} \\
(\mu \mathrm{g} / \\
\left.\mathrm{m}^{3}\right)\end{array}$ & $\begin{array}{l}\mathrm{CH}_{4} \\
\left(\mu \mathrm{g} / \mathrm{m}^{3}\right)\end{array}$ & $\begin{array}{l}\text { TSP } \\
\left(\mu \mathrm{g} / \mathrm{m}^{3}\right. \\
)^{3}\end{array}$ & $\begin{array}{l}\text { PM10 } \\
(\mu g / \\
\left.m^{3}\right)\end{array}$ & $\begin{array}{l}\text { PM2.5 } \\
\left(\mu \mathrm{g} / \mathrm{m}^{3}\right. \\
)^{3}\end{array}$ \\
\hline \multirow{7}{*}{$\begin{array}{l}\text { Ebocha } \\
\text { Town }\end{array}$} & 1 & 31.5 & 77.9 & 1.0 & $\mathrm{NE}$ & ND & ND & 125.0 & ND & 35680.0 & 72.0 & 35.0 & 63.0 \\
\hline & 2 & 31.7 & 77.5 & 0.9 & NW & ND & ND & 125.0 & ND & 71360.0 & 68.0 & 40.0 & 71.0 \\
\hline & 3 & 32.2 & 75.8 & 0.8 & NE & 285.4 & 205.2 & 0.0 & ND & 35680.0 & 70.0 & 39.0 & 63.0 \\
\hline & 4 & 32.3 & 70.4 & 1.6 & NW & 0.0 & 0.0 & 62.5 & 0.0 & 35680.0 & 67.0 & 28.0 & 59.0 \\
\hline & & $31.5-$ & 70.4- & 0.8 & & 0.0 & 0.0 & 0.0 & & $35680-$ & 67.0 & 28.0 & $63.0-$ \\
\hline & Range & 32.3 & 77.9 & 1.6 & & 285.4 & 205.2 & 125.0 & & 71360 & 72.0 & 40.0 & 71.0 \\
\hline & Mean & 31.9 & 75.4 & 1.1 & & 71.4 & 51.3 & 78.1 & 0.0 & 44600.0 & 69.3 & 35.5 & 64.0 \\
\hline $\begin{array}{l}\text { FMEnv } \\
\text { Limit }\end{array}$ & & & & & & 260 & 75 & 22.8 & $\mathrm{NA}$ & 160 & 250 & NA & NA \\
\hline $\begin{array}{l}\text { NAAQS } \\
\text { limit }\end{array}$ & & & & & & 365 & 188.7 & 10000 & $\mathrm{NA}$ & NA & 200 & 150 & 35 \\
\hline
\end{tabular}

$\mathrm{ND}=$ Not detected; NA = Not available

Table: 6: Ranking or Rating of air pollutant for each monitoring area

\begin{tabular}{lcccccccc}
\hline Community & $\mathrm{SO}_{2}$ & $\mathrm{NO}_{2}$ & $\mathrm{CO}$ & $\mathrm{H}_{2} \mathrm{~S}$ & $\mathrm{CH}_{4}$ & $\mathrm{TSP}$ & $\mathrm{PM}_{10}$ & $\mathrm{PM}_{2.5}$ \\
\hline Omoku Town & High & $\mathrm{High}$ & Low & High & High & Low & Low & High \\
Obrikom Town & Nil & Nil & Low & Nil & High & Low & Low & High \\
Ebocha Town & Low & Low & Low & Nil & High & Low & Low & High \\
Control $(5 \mathrm{Km})$ & Low & Nil & Nil & Low & Low & Low & Low & High \\
\hline
\end{tabular}


Table 7: Distance of nearest sensitive receptors from the Existing Facility

\begin{tabular}{llll}
\hline $\mathrm{S} / \mathrm{N}$ & Sensitive receptor & Distance $(\mathrm{Km})$ & Existing Facility \\
\hline 1 & OmokuTowm & 1.6 & OB/OB AGIP gas plant and Rivers State gas turbine \\
2 & Ebocha Town & 0.2 & AGIP gas plant Ebocha \\
3 & Obrikom & 0.7 & OB/OB AGIP gas plant and Rivers State gas turbine \\
\hline
\end{tabular}

Table 8: A Two-factor ANOVA without replication on Omoku pollutants concentration

\begin{tabular}{lcrcccc}
\hline \multicolumn{1}{c}{ Source of Variation } & SS & $d f$ & $M S$ & $F$ & $P$-value & F crit \\
\hline Rows & 2345119398 & 3 & 781706466 & 0.99897283 & 0.412729 & 3.072467 \\
Columns & 33637317196 & 7 & $4.805 \mathrm{E}+09$ & 6.14091778 & 0.000538 & 2.487578 \\
Error & 16432714971 & 21 & 782510237 & & & \\
Total & 52415151565 & 31 & & & & \\
\hline
\end{tabular}

ANOVA= Analysis of Variance; $S S=$ Sum of Squares; $d f=$ degree of freedom; MS= Mean Squares

Table 9: A One-way ANOVA on Obrikom pollutants concentration

\begin{tabular}{lcrrccc}
\hline \multicolumn{1}{c}{ Source of Variation } & SS & $d f$ & MS & $F$ & P-value & F crit \\
\hline Between Groups & 4520092721 & 8 & 565011590 & 5.99154275 & 0.000189 & 2.305313 \\
Within Groups & 2546141048 & 27 & 94301520.3 & & & \\
Total & 7066233768 & 35 & & & & \\
\hline
\end{tabular}

ANOVA= Analysis of Variance; SS= Sum of Squares; $d f=$ degree of freedom; MS= Mean Squares

Table 10: A Two-factor ANOVA without replication on Ebocha pollutants concentration

\begin{tabular}{lllllll}
\hline Source of Variation & $S S$ & $d f$ & $M S$ & $F$ & $P$-value & F crit \\
\hline Rows & 118780012 & 3 & 39593337.2 & 0.994426282 & 0.414700577 & 3.072467 \\
Columns & 6945606822 & 7 & 992229546 & 24.9208379 & $8.17839 \mathrm{E}-09$ & 2.487578 \\
Error & 836120380 & 21 & 39815256.2 & & & \\
& & & & & & \\
Total & 7900507214 & 31 & & & & \\
\hline
\end{tabular}

$\mathrm{ANOVA}=$ Analysis of Variance; $\mathrm{SS}=$ Sum of Squares; $\mathrm{df}=$ degree of freedom; MS= Mean Squares

Table 11: Computed Air Quality Index for the Oil Bearing Communities

\begin{tabular}{lccccccc}
\hline Community & $\mathrm{SO}_{2}$ & $\mathrm{NO}_{2}$ & $\mathrm{CO}$ & $\mathrm{PM}_{10}$ & $\mathrm{PM}_{2.5}$ & $\mathrm{AQI}$ & Rating \\
\hline Omoku Town & 214.1 & 102.6 & 93.8 & 36 & 54 & 153.88 & Unhealthy \\
$\begin{array}{l}\text { Obrikom } \\
\text { Town }\end{array}$ & 0.0 & 0.0 & 62.8 & 32 & 50.5 & 80.11 & Moderate \\
$\begin{array}{l}\text { Ebocha Town } \\
\begin{array}{l}\text { Obite } \\
\text { (Control) }\end{array}\end{array}$ & 71.4 & 51.3 & 78.1 & 35.5 & 64 & 116.50 & $\begin{array}{c}\text { Unhealthy for Sensitive } \\
\text { Groups }\end{array}$ \\
\hline
\end{tabular}




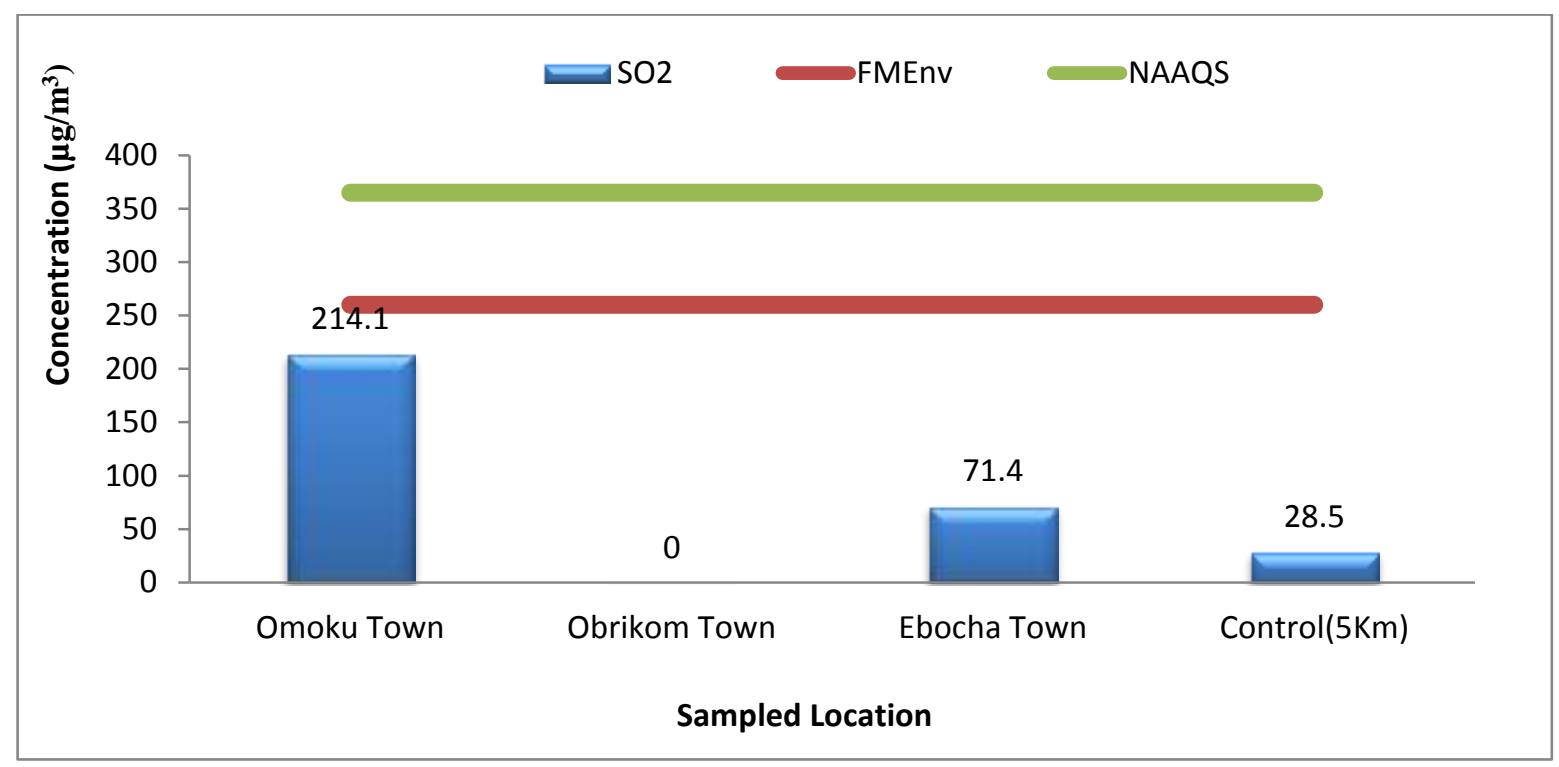

Figure 1: Total average Concentration of $\mathrm{SO}_{2}$ in each sampled location

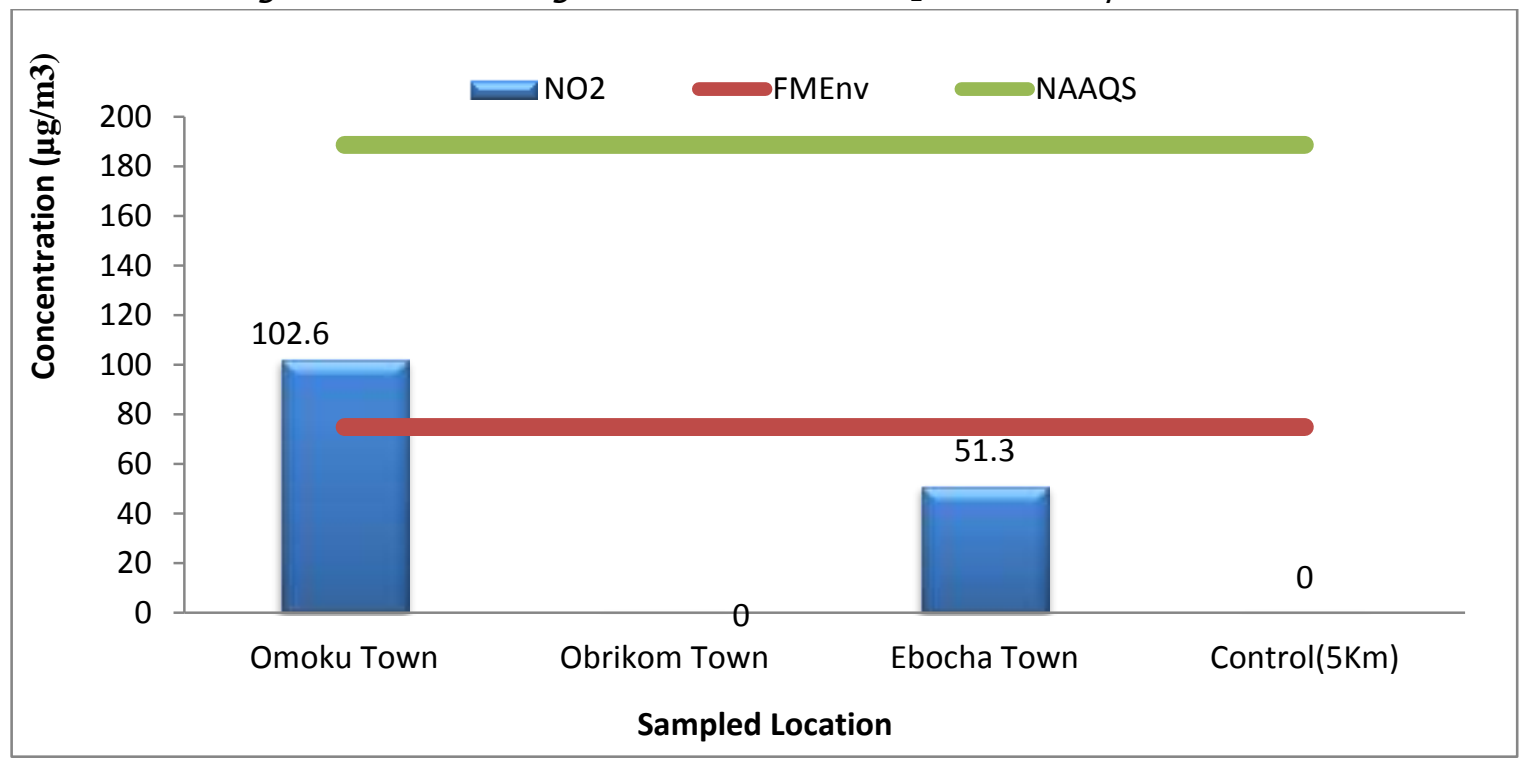

Figure 2: Total average Concentration of $\mathrm{NO}_{2}$ in each sampled location

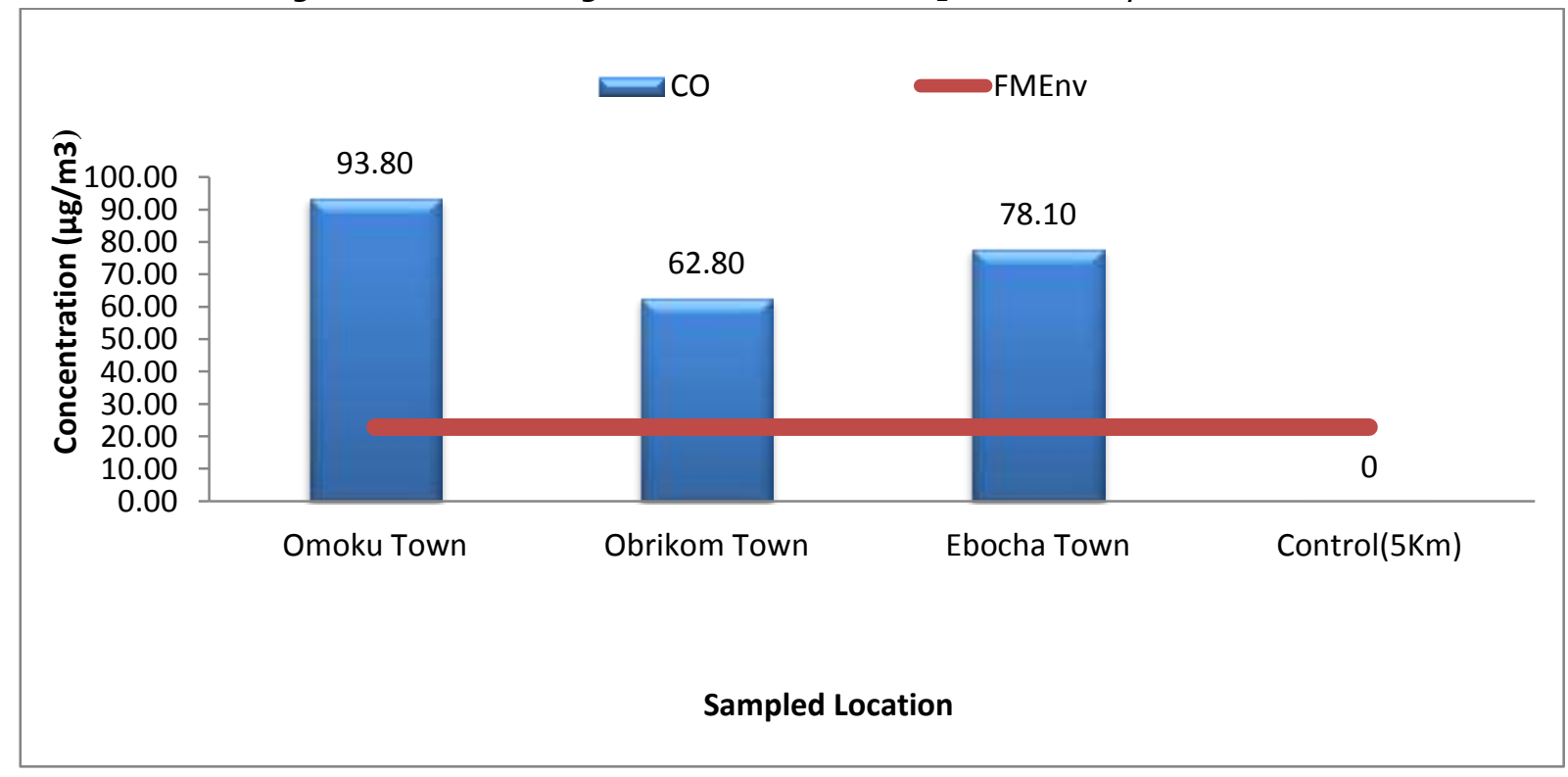

Figure 3: Total average Concentration of $\mathrm{CO}$ in each sampled location 


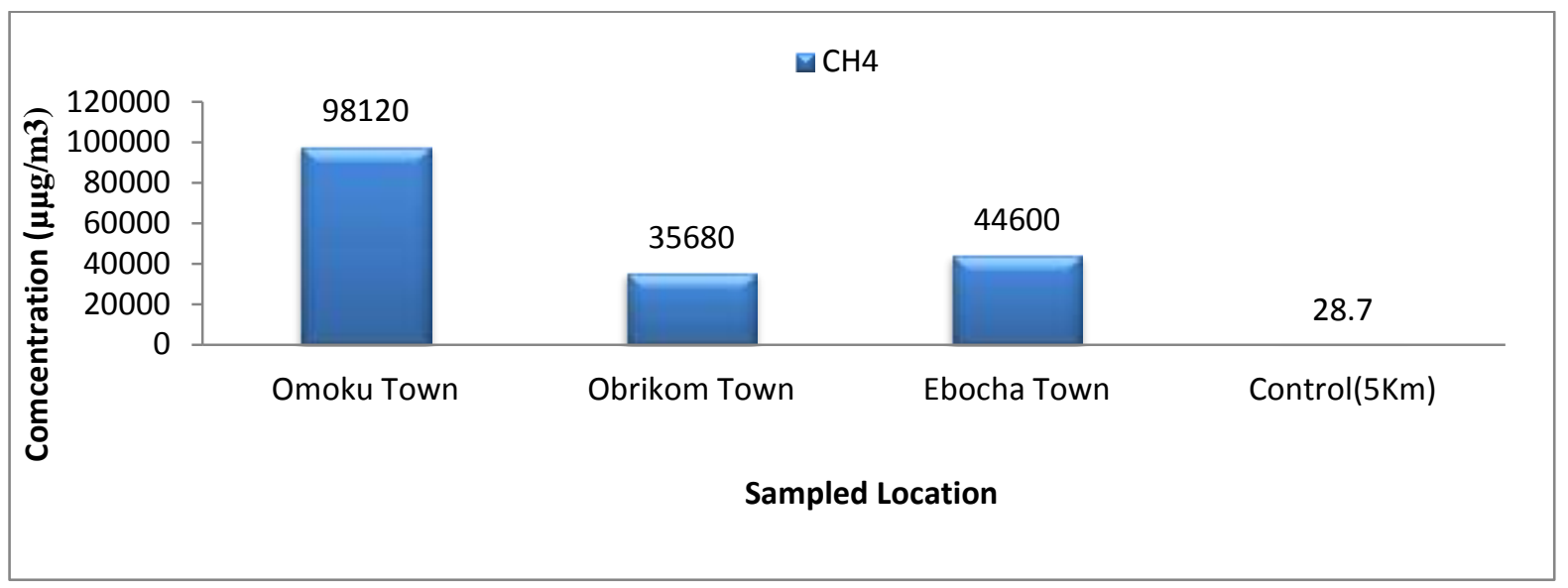

Figure 4: Total average Concentration of $\mathrm{CH}_{4}$ in each sampled location

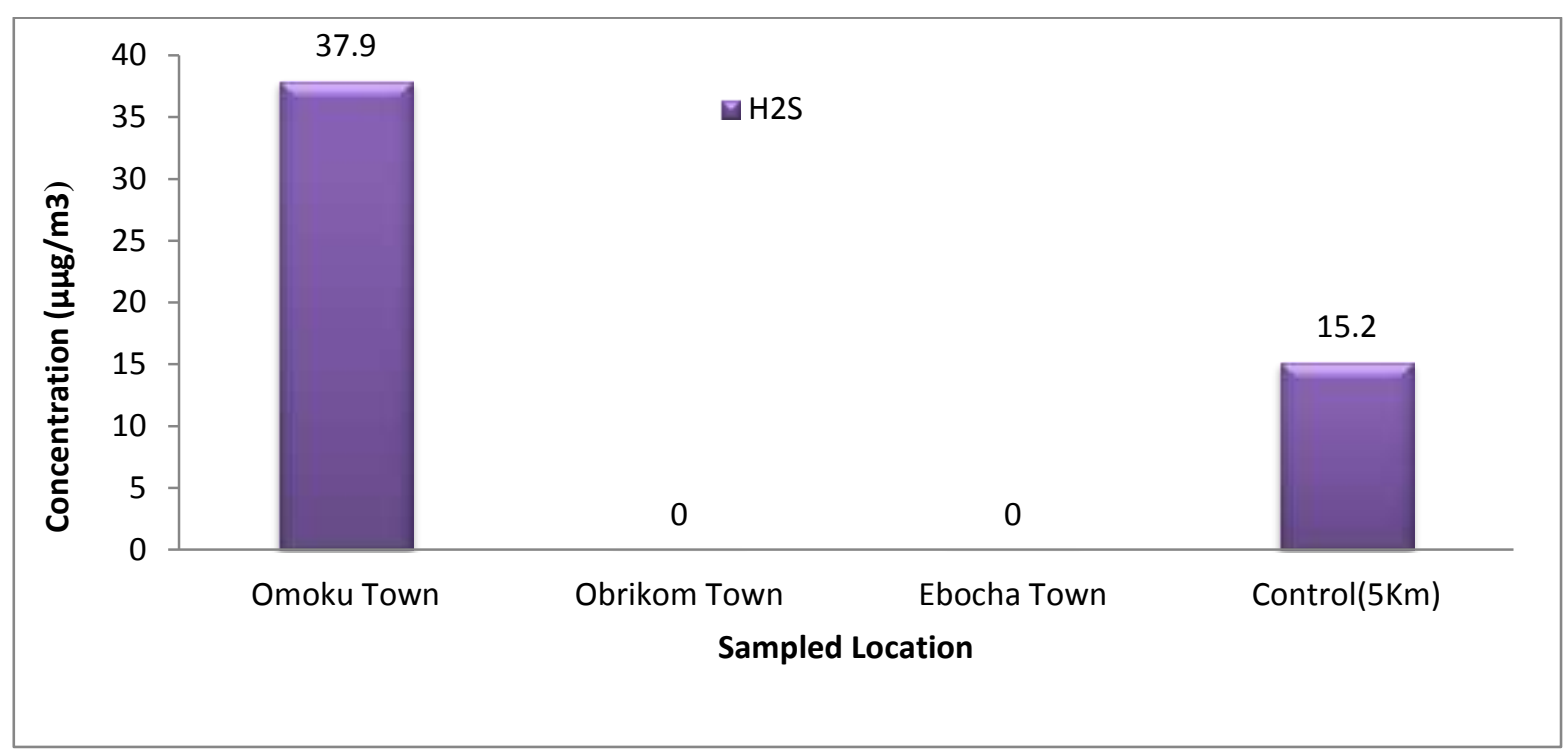

Figure 5: Total average Concentration of $\mathrm{H}_{2} \mathrm{~S}$ in each sampled location

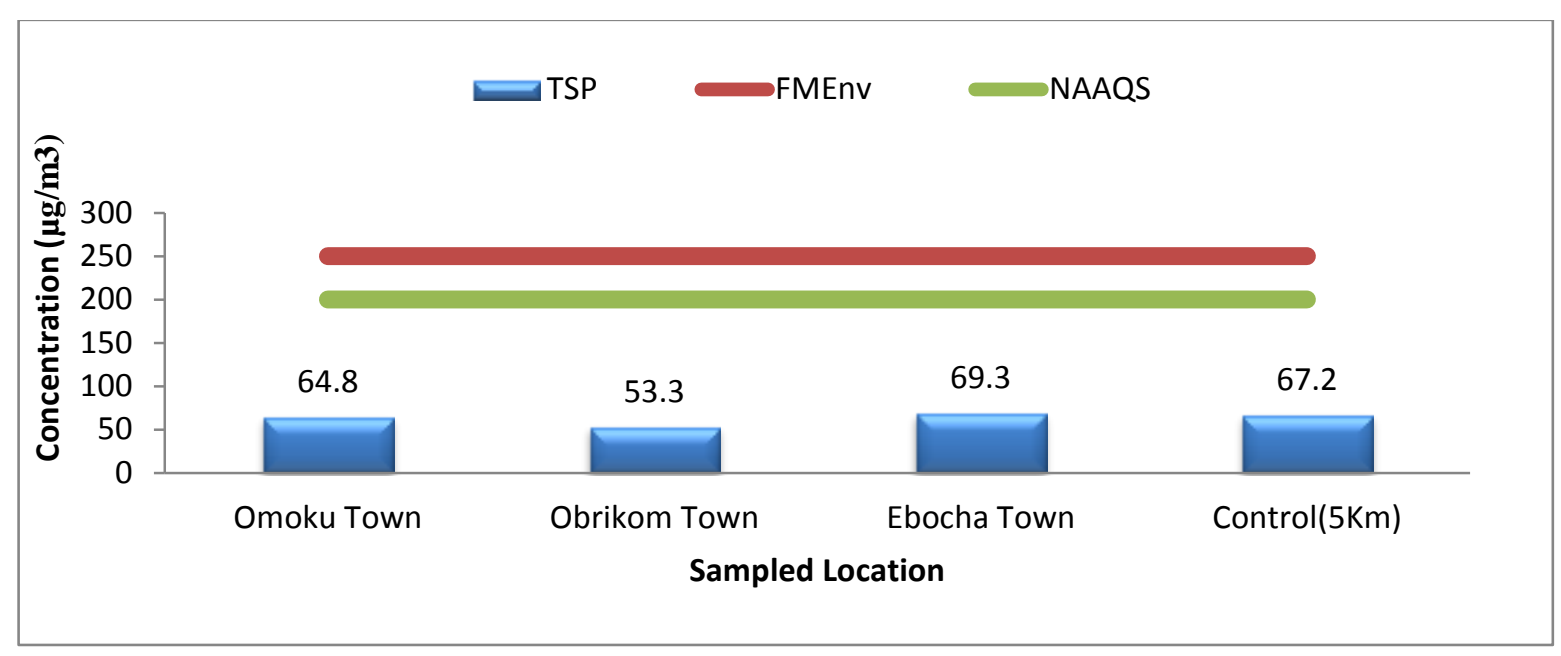

Figure 6: Total average of TSPM in each sampled location 


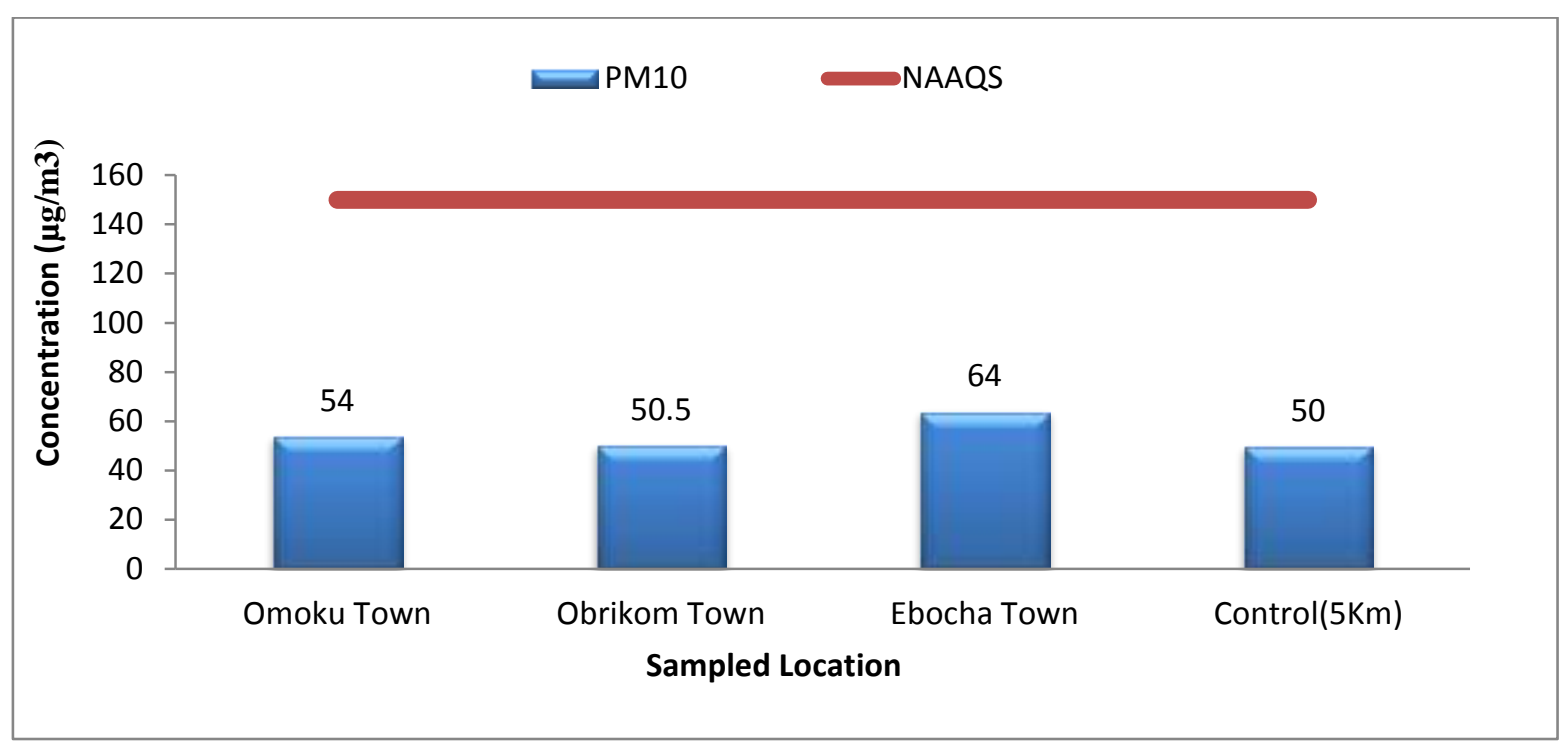

Figure 7: Total average of $P M_{10}$ in each sampled location

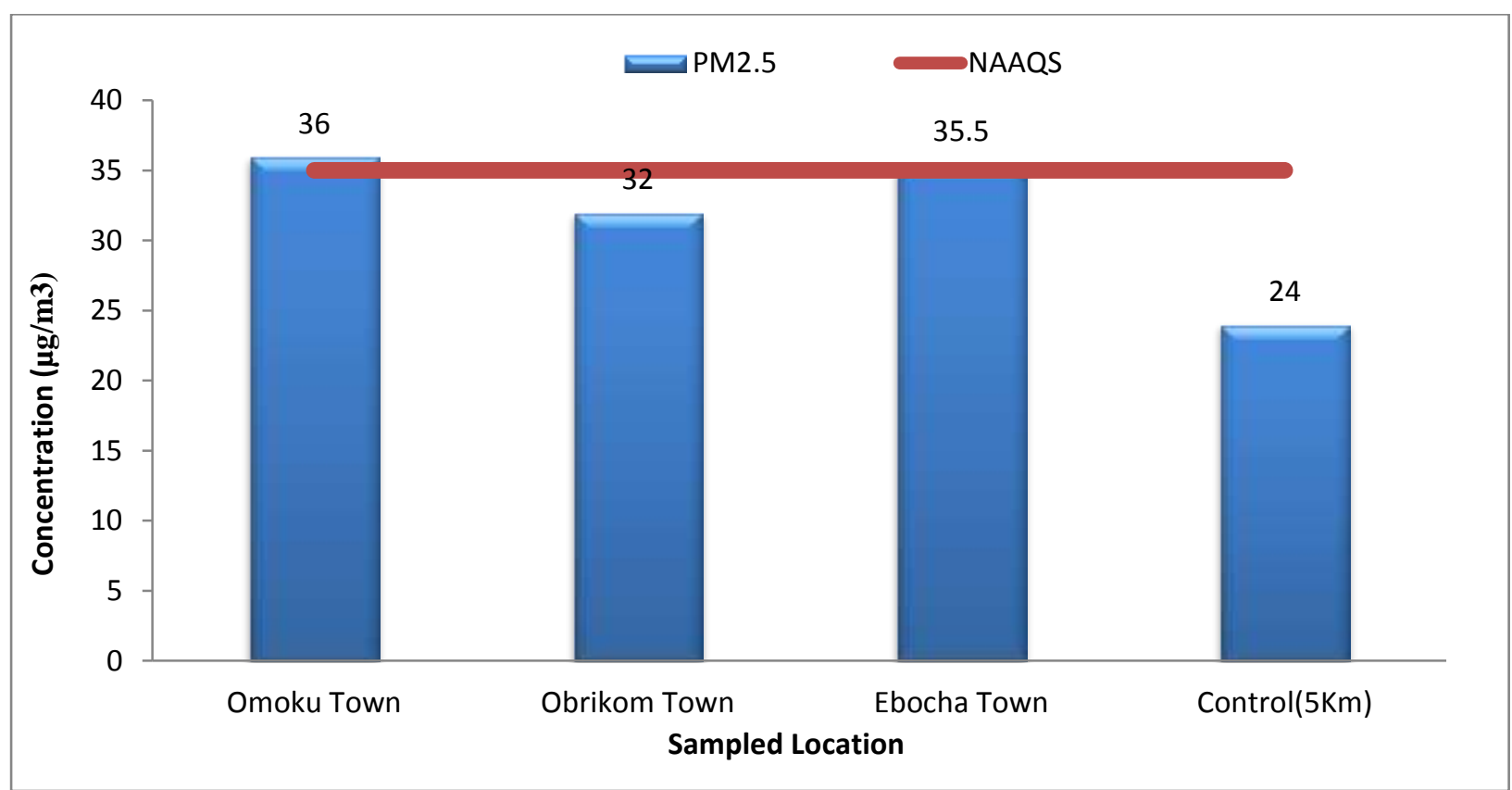

Figure 8: Total average of $P M_{2.5}$ in each sampled location

In Figure 3, $\mathrm{CO}$ at Omoku, Obrikom and Ebocha Towns were $93.8 \mu \mathrm{g} / \mathrm{m} 3,62 \mu \mathrm{g} / \mathrm{m}^{3}$ and $78.1 \mu \mathrm{g} / \mathrm{m}^{3}$ which also exceeded the FMEnv Limit of $22.8 \mu \mathrm{g} / \mathrm{m}^{3}$. The $\mathrm{CO}$ at Omoku and Ebocha were rated unhealthy while at Obrikom it was rated moderate pollution (unsatisfactory) [27, 28]. This assertion was confirmed with the aid of the API rating Scale shown in Table 2.

Figure 8, showed that $\mathrm{PM}_{2.5}$ at Omuku, Obrikom and Ebocha Towns were $54 \mu \mathrm{g} / \mathrm{m}^{3}, 50 \mu \mathrm{g} / \mathrm{m}^{3}$ and $64 \mu \mathrm{g} / \mathrm{m}^{3}$ which exceeded National Ambient Air Quality Standards (NAAQS) Limit of $35 \mu \mathrm{g} / \mathrm{m}^{3}$.The findings were rated unsatisfactory on the API scale (see Table 6). The other measured parameters including $\mathrm{SO}_{2}$, $\mathrm{NO}_{2}$ and $\mathrm{H}_{2} \mathrm{~S}$, were high in Omoku Town, while TSP and $\mathrm{PM}_{10}$ were below Federal Ministry of Environment and NAAQS Limit indicating that these parameters were low and acceptable on API scale (Table 2).

Prolonged exposure to $\mathrm{CH}_{4}, \mathrm{CO}, \mathrm{SO}_{2}, \mathrm{NO}_{2}$ and $\mathrm{H}_{2} \mathrm{~S}$ pollutants in air may result in increased cases of Asthma, and respiratory diseases among the habitants of the communities in the study area. The results were consistent with similar results obtained in the same area by [29]. 


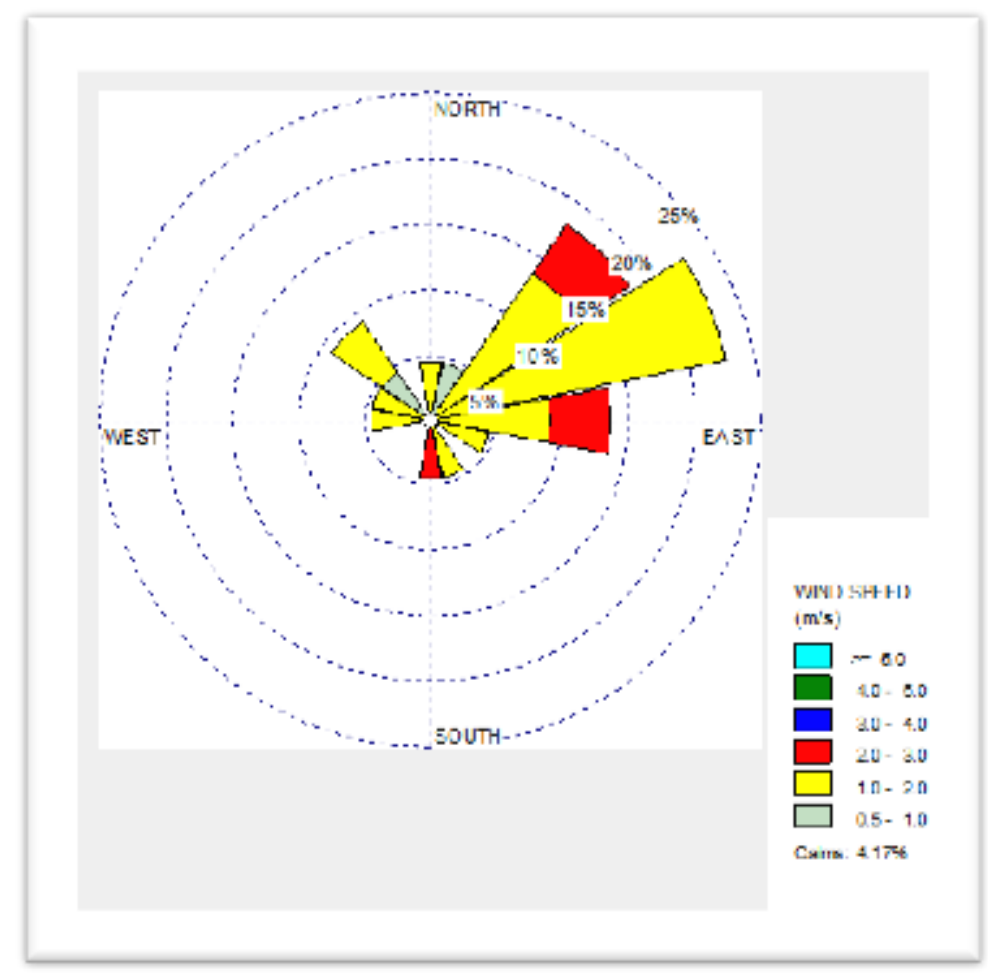

Figure 9: Wind Rose

The distances between Omoku, Obrikom and Ebocha towns from Oil facilities were $1.6 \mathrm{~km} ., 0.7 \mathrm{~km}$ and $0.2 \mathrm{~km}$ respectively (See Table 7 ). While carbon monoxide and hydrocarbon were major pollutants of high impacts on study communities; $\mathrm{SO}_{2}, \mathrm{NO}_{2}$ and $\mathrm{H}_{2} \mathrm{~S}$ impacts in the towns were ranked low $[30,31$, 32].

Tables 8-10 showed the statistical Analysis of Variance (ANOVA) performance at Omuku , Obrikum and Ebocha communities. Results showed that there was no significance difference at the various sampled points at Omuku community but at same time there was significance difference amongst the pollutants characteristics using the 0.05 probability level. There was significant difference at Obrikum community at the 0.05 probability level. At Ebocha community, there was no significant difference between the pollutants characteristics but there a large significant difference in the performance test on pollutants characteristics at the 0.05 probability level during the study period

Air quality indices (AQI) of 153.88, 80.11, 116.5 and 22.57 were computed for Omoku, Obrikom, Ebocha towns and the control town respectively as shown in Table 8. These were rated as unhealthy for Omoku town, Moderate for Obrikom town, unhealthy for sensitive groups for Ebocha town, and good for the control town as shown in Table 8.Themoderate air pollution in Obrikom town may negatively affect the health of few people in the community [33]. It may have minor breathing effects on sensitive people. Also, people with chronic cases of respiratory problems may be at risk. The unhealthy level of air pollution may have harmful impacts on the people of Omoku town. It will aggravate the health conditions of people with respiratory or heart diseases. This level of air pollution in Ebocha was unhealthy for sensitive groups in the community (the elderly, children and people with asthmatic and respiratory cases may be at greater risk).

The surrounding temperature monitored during the study ranged between $30.1^{\circ} \mathrm{C}$ and $32.5^{\circ} \mathrm{C}$ with mean value of $31.3^{\circ} \mathrm{C}$. These temperature values are common tropical climate with high sunshine in the month of November when the field measurement was taken. Average values of ambient temperature in study area were shown in Tables 3-5. Relative humidity ranged between $68.4 \%$ and $78.6 \%$ with a mean value of $74.5 \%$ during the period of field measurement. Irrespective of the season the area experienced high relative humidity that was maximum at dawn (over $90 \%$ ) and minimum by late afternoon $(<60 \%)$. The averages relative humidity in study area were shown in Tables 3-6. Wind speed during the period of field measurement ranged between $0.4 \mathrm{~m} / \mathrm{s}$ to $2.4 \mathrm{~m} / \mathrm{s}$ with a mean value of 
$1.5 \mathrm{~m} / \mathrm{s}$. Wind directions were predominantly NorthEastern, South- Eastern, and North-Western as represented in Wind Rose of Study Area (Tables 3-6 and figure 9).

\section{CONCLUSION AND RECOMMENDATIONS}

The study evaluated air quality in oil bearing communities in Ogba/Egema/Ndoni Local Government Area in Rivers State. Based on results from field monitoring survey and data analysis, the following conclusions were drawn. Activities of oil companies have negative impacts on the natural air quality of the environment within these host communities. Results indicated that host communities were exposed to moderate to high concentrations of hydrocarbon, and carbon monoxide which may adversely aggravate health conditions under prolonged exposure. The researchers advised the government and oil facilities owners to regularly monitor the air quality in the study area. Also, health impact assessment should be conducted on residents of all the host communities to determine the level of impacts on the people.

\section{REFERENCES}

[1] Nkwocha, E. E., Mbonu, E. C. "Effect of Gas flaring on building in the oil producing rural communities of Rivers State, Nigeria". African Research Review, an International Multidisciplinary Journal, Ethiopia, pp91, 2010.

[2] Cedigaz "Gas flaring in Nigeria" A publication in a human right, Environmental and Economic monstrosity Bulletin 15". www.cedigaz.org, pp110, 2000.

[3] Board, C. P. "National Ambient Air Quality Status" Central Pollution Control Board Ministry of Environment \& Forests, http://www.cpcb.nic.in, pp 21, September 2006.

[4] Onunugbo, P. O; Avwiri, G. O and Chad-Umoren Y.E. "Impact of gas exploration on the Environmental radioactivity of Ogba/Egbema/Ndoni Area, Nigeria". Reprinted Energy and Environment, Vol. 22 No 8, 10171028. 2011

[5] Akuro, A. "Air Quality Survey of some locations in the Niger Delta Area". J. Appl. Sci. Environ. Manage. Vol. 16 (1) 125 - 134, 2012.

[6] McCarthy, M.C., Hafner, H. R., Chinkin, L. R., Charrier, J.G. "Temporal variability of selected toxics in the United States". Atmos Environ 41: 7180-7194, 2007.
[7] Wong C.M, Vichit-Vadakan, N, KanH, Qian Z "Public Health and Air pollution in Asia" (PAPA: a multicity study of short-term effects of air pollution on mortality. Environ Health Perspect 116: 1195-1202, 2008.

[8] Kan, H., Chen, B and Hong, C. "Health impact of outdoor air pollution in China current knowledge and future research needs". Environment Health Perspect 117(5): A 187, 2009.

[9] Ugbebor J. N and Yorkor B "Assessment of Ambient Air Quality and Noise levels around selected oil and Gas facilities in Nigeria". Journal of scientific Research and reports 18(6): 1-1, 2018.

[10] Moshammer, H., Hutter, H. P., Hauck, H., Neuberger, M. "Low levels of air pollution induced changes of lung function in a panel of school children". EurRespir J. 27: 1138-1143, 2006.

[11] Nathanson, J. A. "Basic environmental technology". $4^{\text {th }}$ edition, New Jersey 07458, USA 417, 413, 2006.

[12] Allen, R. W, Criqui, M. H, Diez-Roux A.V., Allison, $M$ and Shea, S. "Fine particulate air pollution", proximate to traffic study of Atherosclerosis. Epidemology 20(2): 254-264, 2009.

[13] Gobo, A. E, Ideriah, T J K, Francis, T E, Stanley, $\mathrm{H} O$ "Assessment of Air Quality and Noise around Okrika Communities, Rivers State, Nigeria" J. Appl. Sci. Environ. Manage. March, 2012 Vol. 16 (1) $75-83,2012$.

[14] Shell in Nigeria. Briefing notes, April,. www.shellnigeria.com. 2018.

[15] Igoni, A. H. "Understanding the Niger Delta Environment for Sustainable Agricultural Mechanization". Annual Lecture/Awards Ceremony of the Nigerian Society of Engineers, Port Harcourt Branch, Rivers State, Nigeria, 2018.

[16] Ugorji, M. T. "The Political Economy of Ogba/Egbema/Ndoni people of Rivers State of Nigeria". Canada. 2000

[17] Unachukwu, G. O. "Vehicular Emissions and Air Quality Standards in Nigeria" European Journal of Scientific, vol. 34 No. 4 (2009), pp.550-560, 2009.

[18] Mackenzie, L. D. and David, A. C. "Introduction to Environmental Engineering". McGraw - Hill Companies, Inc; New York, 4edition. Pp120-132, 2008 
[19] World Health Organization (WHO) "Evolution of WHO air quality guidelines: Past, Present and future". Copenhagen: WHO Regional Office for Europe; pp3, 2017.

[20] Rao, M. N and Rao, H. V. N. "Air Pollution". Tata McGraw-Hill Publishing Company Limited, $22^{\text {nd }}$ reprint, New Delhi, India. Chapter 5, 2005.

[21] Leton, T. G. "Pollution Control Engineering (selected topics)". Pearl publishers Port Harcourt, Nigeria. pp 99. 2007

[22] Nwaogazie, I. L., Wilson, A. H., Henshaw, T. "Assessment of standard pollutants in a gas flaring region: A case of Ogba/Egbema/Ndoni L.G. A in Rivers State of Nigeria". International Journal of Civil Engineering and Technology, 793):7-17, 2016.

[23] Kindzierski, W. B., Ohelme-Ayala, P., CamalEl-Din, M. G. "Ambient Air Quality data summary and trend analysis"; Part 1 main report, Wood Buffalo Environmental Association Department of Public Health Sciences, School of Public Health, University of Alberta. USA. pp 9-10, 2009.

[24] World Health Organization (WHO). "Monitoring ambient air quality for health impact assessment". Copenhagen, World Health Organization (WHO) Regional Office for Europe Regional Publications, European Series, No. 85; 1999

[25] United Nations development programme (UNDP). "Niger Delta human development report. Environmental and social challenges in the Niger Delta". UN. House Abuja, Nigeria, 2006.

[26] U.S.E.P.A., "Quality Assurance Handbook for Air Pollution Measurement Systems": Ambient Air Quality Monitoring Program. Office of Air Quality Planning and Standards Air Quality Assessment Division RTP, NC 27711 vol 11; http://epa.gov/air/caa/. 2008.
[27] Obuzor, I. C. (1998). "Economic Impact of Crude Oil Exploration on Farmlands in Ogba/Egbema/Ndoni Local Government Area of Rivers State". B.Sc. Project Report, University of Science and Technology, Port Harcourt, Rivers State. 1998.

[28] Jo P. Dewulf Herman R. and Langenhove, V. "Effect of hydrocarbon on the environment": Environ. Sci. Technol., 2002, 36 (5), pp 11301135, 2006.

[29] Alao, A. A., Avwiri, G. O. "Noise levels associated with selected oil and gas installations in Ogba/Egbema/Ndoni Local Government Area of Rivers State, Nigeria". Journal of Environmental Issues and agriculture in Developing Countries, 2(2-3), 2010.

[30] Federal Environmental Protection Agency (FEPA) "Guidelines and Standards for Environmental Pollution Control in Nigeria". Federal Ministry of Environment, Nigeria, 1991.

[31] OSHA "Fact sheet on Hydrogen Sulphide $\left(\mathrm{H}_{2} \mathrm{~S}\right)$ ". U.S. Department of Labor. September 2005OSHA www.osha.gov (800) 321OSHA, 2005.

[32] World Health Organization (WHO). "Global air quality guidelines for particulate matter, ozone, nitrogen dioxide and sulfur dioxide" Summary of risk assessment. Geneva, World Health Organization (http://whqlibdoc.who.int/hq/2006/WHO SDE P HE OEH 06.02 eng.), 2006.

[33] World Health Organization (WHO) "Indoor air pollution and health". Geneva, World Health Organization (WHO Fact Sheet No. 292; http://www.who.int/mediacentre/factsheets/fs29 2/en/index.html), Pp1-5, 2005. 